\title{
A Review on Diversity, Bio-Ecology, Floral Resources and Behavior of Blue Banded Bees
}

\author{
J. Sandeep Kumar ${ }^{*}$, B, Rex $^{2}$, S. Irulandi ${ }^{3}$ and S. Prabhu ${ }^{3}$ \\ ${ }^{1}$ Department of Entomology, Agriculture College and Research Institute, \\ Madurai-625104, India \\ ${ }^{2}$ Department of Plant Pathology, Agriculture College and Research Institute, \\ Madurai-625104, India \\ ${ }^{3}$ Department of Plant Protection, Horticulture College and Research Institute, \\ Periyakulam-625604, India \\ *Corresponding author
}

\section{A B S T R A C T}

Ke y w or d s
Blue banded bees,
Amegilla, Diversity,
Behavior, India
Article Info
$\begin{aligned} & \text { Accepted: } \\ & \text { 07 June } 2019 \\ & \text { Available Online: } \\ & \text { 10 July } 2019\end{aligned}$

Blue banded bees are solitary bees which are characterized by their glittering blue color bands on their abdomen. They construct their nests and brood cells for their young ones in soils. The developmental biology of blue banded bees is maximum sixty days and varied according to climatic conditions. They are polylectic and wild pollinators playing major role in crop pollination. Research on blue banded bees is very limited and less studies. In this review we will focus on diversity, bio-ecology and behavior of blue banded bees.

\section{Diversity of blue banded bees}

Blue banded bees are Anthophorine bees. An Anthophorine bee was first described by Linneaus in 1758 as Apis retusa. Latreille described first Anthophorine genus in 1802 and in 1803 he proposed the name Anthophora. Fabricius named a genus as Megilla in 1805. The name Megilla is now regarded as a junior synonym of Anthophora by Michener, (1974). Anthophorine bees are now grouped under the family Apidae, sub family Apinae and tribe Anthophorini
(Brooks, 1988; Michener, 2000). The two important genera of the tribe Anthophorini are Anthophora and Amegilla which are easily distinguished based on the presence or absence of arolium. The male genetalia of different Anthophorine bees vary distinctly (Brooks, 1988). They frequently bear metallic blue or green pubescent bands on metasomal terga. They fly in summer. This genus includes 12 sub genera and 253 species (Brooks, 1988). The genus Amegilla is a diverse group of approximately 255 Anthophorine bee species distributed in 
southern Europe and Mediterranean basin southward throughout Africa and Madagascar east into Arabia and in Asia as far as northeast China, India, Sri Lanka, Indonesia, New Guinea as well as Australia (Engel, 2007). In the oriental region there is a large diversity of blue banded bee species that are frequently confused with each other, typically being identified as the relatively widespread Amegilla zonata. Closer examination of these bees reveals that there are multiple distinct species among Southeast Asian "zonata". Engel (2007) described a new species of Amegilla from zonata group and named it as Amegilla anekawarna Engel from Malaysia. The new species is similar to A. zonata but can be distinguished by the presence of a distinct medioapical blue band on fifth metasomal tergum and by the yellow ventral surface of scape in the female and presence of two dark clypeal markings in male. Rayment (1951) revised 15 Australian species of blue banded bees and grouped them under the genus Asaropoda. A. dawsoni is Australia's largest Anthophorine bee. In these species two types of males i.e. large and small males are present. Males exhibit a bimodal size frequency distribution. Amegilla is the only genus occuring in Australia where it is represented by three subgenera Asaropoda, Notomegilla and Zonamegilla (Brooks, 1988). Lieftinck (1956) revised the oriental Anthophorine bees of the genus Amegilla and described sixteen species under these genus occuring both in Malaysia and Southeast Asia. Lieftinck (1975) redefined four species of Amegilla complex viz., A.florea, A.confusa, A. parhypate and A.calceifera in Korea. Brooks (1988) proposed a subgeneric name Glossamegilla for Amegilla sp. with long glossa collected from India to the IndoMalayan regions and included 29 species in the group. Attasopa and Warrit (2012) redescribed the subgeneric position and distribution of oriental burrowing bee, Amegilla fimbriata. Michener (1956) included
Amegilla in his revision of Egyptian Anthophora species Engel (2007) described new species of Amegilla from northeastern Egypt viz., Amegilla argophenax and differentiated same from the commonly occurring species. Blue banded bees shows sexual dimorphism, opposite sexes can be differentiated based on their body size where male bees are smaller than female bees, head appendages (Clypeal markings are absent in male bees, mandibles are short in male bees, antenna is short in female bees than males, number of flagellomeres are eleven in male and ten in female, compound eyes are small in male bees and sting is absent in male bees) and blue color metallic bands on metasoma. Gonostylus is lessen to a blister in male bee (Sandeep and Muthuraman, 2018).

\section{Nesting biology}

Several workers studied the soil nesting behavior of Anthophorine bees (Thorp, 1969; Torchio 1974; Brooks, 1983; Norden, 1984; Houston, 1991; sandeep and Muthuraman, 2018). Blue banded bees are fossorial bees and build their nests underground (Cane, 1981). Their nests are burrows in soil, either in banks or in flat ground (Michener, 1960). The female bee also pays attention for the surface nature of nesting site and edaphic attributes of the soil (Cane, 1991). These bees build nests in a variety of soil types like black soil, clay soil and sandy soil but they always prefer a site with some shelter (Rayment, 1951). Anthophora edwardsii preferred crumbly clay-silt in the open areas to loose sandy silt in the vegetated areas (Thorp, 1969). Many soil-dwelling solitary bees make their nests in groups or aggregations where females nest gregariously and a clumped nest distribution is found (Batra, 1978). The female bee prefers to build the nest at the nesting sites from where it emerged as an adult. This phenomenon is termed as philopatry. The philopatry may be a probable reason for nest 
aggregations (Norden, 1984). In initiating a new nest, a female selects a site and begins to excavate a burrow by biting at the soil with her mandibles. The soil is periodically moistened and softened with liquid from the mouth. Females interrupt their burrowing from time to time and depart on flights away from the nesting area presumably to recharge their crop with liquid (Houston, 1991). Ground nesting bees sometimes conceal their nest entrances in loose sand under clods or in dense vegetation. However, most of them leave some kind of mound or other tell-tale mark at the entrance. The nests are shallow seated inside the soil and usually less than 10 $\mathrm{cm}$ deep. Excavated soil on horizontal surfaces is often heaped in a small cone or delta of irregularly sized pellets, near the nest entrance (Cane, 2008). Chimney bee A.abrupta digs a tunnel for its nest and uses the excavated soil to build a chimney or turret near nest entrance. Each turret corresponds to a single nest (Norden, 1984). Turrerts give protection to nest from rain, nearby excavations, windblown debris or parasites. They also function as a land mark for nest recognition and thermoregulation of nest (Brooks, 1983; Norden, 1984). The burrow descends down as a shaft which ends in urnshaped terminal cell or a cluster of cells or in a linear series. The inside of the cell is extremely smooth and polished and then covered with a heavy layer of white, water proof material may be flaked off from the cell wall made of Dufour's gland lipids (Thorp, 1969; Cane, 1991). The various substrates suitable for nesting were studied under pot culture experiment. Red soil and potting mixture were recorded for best substrates for nesting. Mostly nests were found close to edge of pot. The female bee digs out her own nest burrow of depth $4-30 \mathrm{~cm}$ using her strong mandibles and excavated soil by her legs forming a tumulus and some bees formed turrets $(1.2$ to $4.8 \mathrm{~cm})$. The nest shaft extends from entrance to a cluster of earthen brood cells. Brood cells are cylindrical and urn shaped. Waxy coatings were found in inner cell wall of brood cells which would be used for water proof and larval feed, larval faeces and cast skin was found inside the brood cell. Nests are often built together in one place forming nest congregation and the maximum number of nests was 78 per $\mathrm{m}^{-2}$ (Sandeep and Muthuraman, 2018).

\section{Developmental biology}

Blue banded bees are fossorial bees. The life stages of the bees develop inside sealed earthen brood cells. More often invasive methods are used for studying the life stages of these bees. Of late X-ray computerized tomography (CT) scanning is used to study the developmental biology and natural enemies of bees (Greco et al., 2006). As in all Hymenopteran insects the sex is determined by haplodiploidy mechanism. The male bees develop from haploid eggs and female develop from diploid eggs. The bee larvae are reared through mass provisioning. The larval food may be a thick liquid or semi-solid in consistency. Immature life stages of Amegilla, Asaropoda and Anthophora are similar in morphology (Cardale, 1967). In A.dawsoni the female is capable of producing two kinds of male's viz., namely major males and minor males by constructing larger and smaller brood cells and provisioning the cells with different amount of food (Tomkins et al., 2001). Females of Dawson's burrowing bees have a well-defined brood cell cycle involving cell construction, waxing, provisioning, egg laying and cell capping (Alcock, 1998). Eggs are singly laid by the female bee on the larval provision (Cane, 1984). Eggs hatched in about five days and the larvae developed through four instars by eating the larval provision. The last instar larva after consuming larval provisions consumed the cell linings and defaecated within the cell which formed the basal lining 
of the cell and turned into prepupa without moulting. They do not spin cocoons. Bees over wintered as prepupae under temperate conditions and completed one generation in a year. In tropical conditions the developmental arrest was not found. In A. abrupta egg period lasted for 5 days, larval period for 21 days and pupal period for 18 days (Norden, 1984). Cardale (1967) reported the natural enemies associated with Amegilla pulchra. He found out a cleptoparasitic bee (Thyreus caeruleopunctatus), a Sarcophagid fly (Miltogramma sp), a Meloid beetle (Zonitis $s p$ ), a mite (Pymotes ventricosus) and a fungus (Aspergillus $s p$ ). Norden and Scarbrough (1982) studied about three important parasites affecting Anthophora abrupta. They recorded a Conopid fly (Physocephala marginata) as an adult parasite. Green metallic cuckoo bee (Chrysis sp) was parasitic on immature stages. A Meloid beetle (Hornia minutipennis) was found to feed on bee eggs and larval provisions. Houston (1991) found out a Sarcophagid fly (Tayloromyia iota) affecting the adult female bee, A.dawsoni. The endoparasitic maggots killed the parasitized bee. Eggs are laid individually on bee bread $(0.07 \mathrm{~g})$ in the brood cell was mass provisioned by the bees. The first and second instar larva was straight and slightly pigmented mandibles respectively. Third instar larva was ' $C$ ' shaped along with small amount of unutilized brood food. The fourth instar larva almost occupies the brood cell without any food materials. Larva consumes wax linings and shrinks slightly before turning into a prepupa. Pupal eye coloration changes from yellow to orange and then to brown and finally black as the pupa matures. The adult bee emerges fifteen days after pupation. It was found that the development of bees were pretentious by heavy rains and brood mites (Rhizoglyphus sp. and Histiostoma sp.) (Sandeep and Muthuraman, 2018).

\section{Floral resources}

Studies on foraging resources of blue banded bees are scanty. The bee foraged on both wild and cultivated flora and hence they constituted an important component of the pollinator guild of an area. The species of the plant family's Verbanaceae, Lamiaceae, Acanthaceae were more preferred by these bees for the collection of floral rewards. These bees were able to compete with other anthophilous insects in sharing floral resources. Flowers with white, purple, blue and yellow were more attractive for this bees. Intra floral behavior of avoiding stigma contact while foraging on Moringa oleifera and Bauhinia purpurea reduced the chances of pollination. Amegilla was found to be a rapid flier and even few individuals covered a large number of flowers in their foraging trip (Subba reddi et al., 1999). The foraging behavior of a blue banded bee Amegiila chlorocyanea was studied in Australian tomato greenhouses by (Hogendoorn et al., 2007). Their study revealed the foraging potentiality and the practical utility of blue banded bees for pollinating tomato grown in greenhouses instead of using the exotic bumble bees.

They were active foragers and performed on an average nine pollen flights per day when foraging in a tomato greenhouse. The bees collected pollen from the anthers by shaking the flowers in flight (Hogendoorn et al., 2006). The flight activity of both male and female bees started early morning around 6:00am ends during sunset at 6:30pm and collect floral nectar or pollen. These bees preferred various plants from Fabaceae, Solanaceae and Cucurbitaceae. These bees collected pollen or nectar from 12 weeds and 21 crop plants and they are attracted mainly to yellow coloured flowers followed by white and purple colors (Sandeep and Muthuraman, 2018). 


\section{Behaviour}

Male bees were found in both nesting areas and at forage sites. At nesting areas, they fly slowly over the ground (within $15 \mathrm{~cm}$ of the surface) following meandering paths. They paid particular attention to holes without turrets which they frequently inspect and sometimes entered briefly. They pay no attention to turreted burrows or females entering or leaving them. The male bees wait at the nest entrance for the virgin female bee to come out. They can detect the presence of female bee even while she is inside the tunnel. The male bees fight with each other using their mandibles and winning bee alone can mate with female bee (Houston, 1991). Mating occurs at nesting areas and mainly at the forage sites. The female bee normally mates only once and mating lasts about seven minutes in Amegilla dawsoni (Simmons et al., 2000). The female, mounted by the successful male, ran over the ground for some meters until the pair was hidden beneath some small plants and there coupling lasted for about two minutes (Houston, 1991). Males conducted apparent searching maneuvers by darting from flower to flower and hovering above each blossom for one to two seconds. They occasionally stopped to drink nectar, but then resumed their flights. Mating was initiated after a male hovered for approximately one second above a feeding female. He flew rapidly to the female, butted her abdomen with his head, and then grasped her thorax with his fore and mid legs. While in a dorsal position, his genitalia were inserted and his abdomen began a pumping motion. Male mouthparts were sometimes extended and stroked the female's head. Copulation lasted between 15 and 45 seconds with females remaining passive throughout in A.abrupta (Norden, 1984). Previously mated females were occasionally mounted by other males, but always avoided copulation. Males also commonly butted other feeding males but did not mount them. It is not known if contacts between males were a result of mistaken identity or aggression (Norden, 1984). These brief encounters resulted in both males departing. Similar encounters between male Anthophora occidentalis were noted by Batra (1978). Sleeping aggregations have been observed in various solitary bees by Michener (1974). Such aggregations consist of usually conspecific males rarely with few females gathering on plant stem. In most of the Hymenopteran species males have been observed spending the night on flowers or leaves but most of the females spend the night in burrows or nest structures. However, males of several solitary bee and wasp species have observed aggregating in a specific location overnight. Female biased aggregations of Amegilla florea were reported by Yokoi and Watanabe (2014) in Japan. The sleeping aggregation observed was unusually female biased and occurred on dead branches. The sex ratio and number of sleeping individuals in the sex mixed aggregation changed daily. Female arrived later but left earlier than male to avoid long stay with male. The sleeping sites were shared by both the sexes for want of enough places to sleep. Aggregation behaviours have been reported in males since the 1800s. Target locations and substrates for sleeping aggregations include branches, plant stems, leaves and flowers. Individuals often return to the same site in the late afternoon or evening, reforming the aggregation in the same location for weeks, months (Linsley, 1962; Alvis-dos-santos et al., 2009). Gregarious sleeping was observed in Amegilla garrula in Italy by Aldini (1994). The aggregation had both male and female. However no mating occurred at the aggregation site. Female bee guards the nest by remaining within the nest shaft. They hover around the intruder at nest congregation site but they do not sting. They sting only when provoked or roughly handled at nesting, foraging and sleeping sites without losing 
their sting. Most of the sleeping clusters are intraspecific and male biased and rarely sex mixed. Males take rest during dusk either singly or in a cluster on the terminal end of the dried weeds (Achyranthes aspera, Chloris barbata and Vicoa sp) by grasping the stem firmly with their mandibles and fall asleep. Interspecific sleeping clusters are also found occasionally which involved cuckoo bees (Thyreus sp.) and leaf cutter bees (Megachile sp.). When both the sexes are brought together and confined in enclosures forced mating can occur (Sandeep and Muthuraman, 2018).

India has a very large bee fauna, but often threatened by agricultural practices and natural calamities. There few basic information about biology and behavior of blue banded bees in India. Studies on distribution and taxa of blue banded bees are very limited. Hope this review will encourage more researchers to work on these bees. Future work on developmental and pollination studies will help farmers to employ a cost effective pollinators in their ecosystem.

\section{References}

Alcock, J., 1998. Sleeping aggregations of the bee Idiomelissodes duplocincta (Cockerell) (Hymenoptera: Anthophorini) and their possible function. Journal of Kansas Entomological Society. 71, 77-84.

Aldini, RN., 1994. Preliminary observations on gregarious sleeping in Amegilla garrula (Hymenoptera: Apoidea: Anthophoridae). Ethology Ecology and Evolution. 3,131-135

Alvis-dos-santos I, Gaglianone MC, Naxara SRC and Engel MS. 2009. Male sleeping aggregation of solitary oil collecting bees in Brazil (Centridini: Tapinotaspidini and Tetrapediini:
Hymenoptera: Apidae). Gentetics Molecular Research. 8, 515-524.

Attasopa, K., and Warrit N. Redescription, subgeneric position and distribution of the Oriental burrowing bee, Amegilla fimbriata (Hymenoptera: Apidae: Anthophorini). Pan-pacific Entomology. 88 (3): 281-291.

Batra, SWT, 1978. Aggression, Territoriality, Mating and Nest Aggregation of some Solitary Bees (Hymenoptera: Halictidae, Megachilidae, Colletidae, Anthophoridae). Journal of Kansas Entomologocal Society. 3 (51): 547559.

Bell MC, Spooner-Hart RN and Haigh AM. 2006. Pollination of greenhouse tomatoes by the Australian blue banded bee Amegilla (Zonamegilla) holmesi Rayment (Hymenoptera: Apidae). Journal of Economic Entomology. 99, 437-442.

Brooks, RW, 1983. Systematics and bionomics of Anthophora: The Bomboides group and species group of the new world. University of California Publications in Entomology.98, 1-84.

Brooks, RW, 1988. Systematics and phylogeny of the anthophorine bees (Hymenoptera: Anthophoridae; Anthophorini). University of Kansas Science Bulletin. 53(9): 436-575.

Buchman, SL., 1992. Buzzing is necessary for tomato flower pollination. Bumblebeequest. 2, 1-3.

Butler, CG, 1965. Sex attraction in Andrena flavipes Panzer (Hymenoptera, Apidae) with some observations on nest-site restriction. Proceedings of Royal Entomological Society. 40, 77-80.

Cane, JH, 1981. Dufour's gland secretion in the cell linings of bees (Hymenoptera: Apoidea). Journal of chemical Ecology.7, 403-410.

Cane, JH, 1991. Soils of ground-nesting bees (Hymenoptera: Apoidea): texture, 
moisture, cell depth, and climate. Journal of Kansas Entomological Society. 64,406-413.

Cane, JH, 2008. Bees (Hymenoptera: Apoidea: Apiformes). Encyclopedia of Entomology. Springer, Florida. 2,419434.

Cane, JH, and Carlson RG. 1984. Dufour's gland triglycerides from Anthophora, Emphoropsis (Anthophoridae) and Megachile (Megachilidae) bees (Hymenoptera: Apoidea). Comparative Biochemistry and Physiology. 78 (3): 769-77.

Cardale, J., 1967. Nest and nesting behavior of Amegilla pulchra (Smith) (Hymenoptera: Apoidea: Anthophoridae). Australian Journal of Zoology. 16, 689-707.

Engel, MS., 2007. A new Amegilla of the zonata group from Malaysia and Thailand (Hymenoptera: Apidae). Transactions of Kansas Academy of Sciences.10 (1): 16-22.

Engel, MS., 2007. A new species of Amegilla from northeastern Egypt (Hymenoptera: Apidae). Linzer biologische Beitrage. 39 (2): 821-828.

Greco M, Bell M, Hart RS, and Holford P. 2006. X-ray Computerized Tomography as a new method for monitoring Amegilla holmesi nest structures, nesting behaviour, and adult female activity. Entomologia Experimentalis et applicata, 120, 71-76.

Hogendoorn K, Coventry S, and Keller MA. 2007. Foraging behavior of a blue banded bee, Amegilla chlorocyanea in greenhouses: implications for use as tomato pollinators. Apidologie.38 (1): 86-92.

Hogendoorn K, Gross CL, Sedgely M, and Keller MA. 2006. Increased tomato yield through pollination by native Australian Amegilla chlorocyanea (Hymenoptera: Anthophoridae). Journal of Economic Entomology. 99(3): 828833.

Houston, TF, 1991. Ecology and behaviour of the bee Amegilla (Asaropoda) dawsoni (Rayment) with notes on related species (Hymenoptera:

Anthophoridae) Records of the Western Australian Museum. 5: 591-609.

Lieftinck, MA, 1956. Revision of some Oriental Anthophorine bees of the genus Amegilla Friese (Hymenoptera: Apoidea). Verhandlungen Der Zoologisch. 30, 1-41.

Lieftinck, MA, 1975. Bees of the genus Amegilla Friese from Korea with a new species (Hymenoptera: Anthophoridae). Annals of Natural History Museum. 67, 279-292.

Linsley, EG, 1962. Sleeping aggregations of aculeate Hymenoptera-II. Annals of Entomological Society of America. 55,148-164.

Michener CD. 2007. The Bees of the World, 2nd ed. Johns Hopkins University Press, Baltimore, Maryland, pp.1- 953.

Michener, CD, 1960. Observations on the behavior of a burrowing bee (Amegilla) (Hymenoptera, Anthophorinae). Queens Land Natural History Award. 16: 63-67.

Michener, CD, 1961. Observations on the nests and behaviour of Trigona in Australia and New Guinea (Hymenoptera: Apidae). American Museum Novitates. 2026, 1-45.

Michener, CD, 1974. The Social Behavior of the Bees: a Comparative Study. Cambridge, Massachussetts: Harvard University Press.

Michener, CD, 2001. The Bees of the world, University of Kansas Natural History Museum and Departament of Entomology, The John Hokins University Press, Baltimore and London., pp.1- 913.

Michener, CD., Revision of some Oriental Anthophorine bees of the genus, 
Amegilla Friese. Zoologische Verhandelingen. 30, 1-41.

Norden, BB, 1984. Nesting Biology of Anthophora abrupta (Hymenoptera: Anthophoridae). Journal of Kansas Entomological Society. 57 (2): 243-262.

Norden, BB, and Scarbrough AG. 1982. Predators, parasites, and associates of Anthophora abrupta (Hymenoptera: Anthophoridae). Journal of New York Entomological Society. 90 (3): 181-185.

Rau, P., 1929. The biology and behavior of mining bees, Anthophora abrupta and Entechnia taurea. Psyche. 36 (3): 155181.

Rayment, T., 1951. A critical revision of species in the genus Asaropoda by new characters. Memoirs of the Natural Museum of Victoria.127, 65-80.

Sandeep, KJ, and M Muthuraman. 2018. Morphometric studies on blue banded bees, Amegilla zonata L. (Apidae: Hymenoptera). Journal of Entomology and Zoological studies. 6(5): 23462350.

Sandeep, KJ, and M Muthuraman. 2018. Behavior of blue banded bees, Amegilla zonata L. (Apidae: Hymenoptera). Journal of Entomology and Zoological studies. 7(1): 428-434.

Sandeep, KJ, and M Muthuraman. 2018. Bioecology of blue banded bees, Amegilla zonata L. (Apidae: Hymenoptera). Journal of Entomology and Zoological studies. 6(5): 2365-2370.
Simmons LW, Tomkins JL, and Alcock J. 2001. Can minor males of Dawson's burrowing bee, Amegilla dawsoni (Hymenoptera: Anthophorini) compensate for reduced access to virgin females through sperm competition. Behavioral Ecology. 11 (3): 319-325.

Subba reddi C, Raju JS, and Atluri JB. 1991. Foraging and pollination by the digger bee Amegilla. Asian Bee Journal.1 (1): 38-43.

Thorp, RW, 1969. Ecology and Behaviour of Anthophora edwardsii (Hymenoptera: Anthophoridae). The American Midland Naturalist Journal. 82 (2): 321-333.

Tomkins JL, Simmons LW, and Alcock J. 2001. Brood-provisioning strategies in Dawson's burrowing bee, Amegilla dawsoni (Hymenoptera: Anthophorini). Behavioral Ecology and Sociobiology.50, 81-89.

Torchio, PF, 1974. Notes on the biology of Anylocelis armata Smith and comparisons with other Anthophorine bees. Journal of Kansas Entomological Society. 47, 54-63.

Yokoi, T., and Watanabe M. 2014. Female biased sleeping aggregations of Amegilla florea urens (Hymenoptera: Apidae). Entomological Science. Laboratory of Conservation Ecology, Faculty of Life and Environmental Sciences, University of Tsukuba, Tsukuba Ibaraki.

\section{How to cite this article:}

Sandeep Kumar, J., B, Rex, S. Irulandi and Prabhu, S. 2019. A Review on Diversity, BioEcology, Floral Resources and Behavior of Blue Banded Bees. Int.J.Curr.Microbiol.App.Sci. 8(07): 580-587. doi: https://doi.org/10.20546/ijcmas.2019.807.072 